\title{
Revisionism of Powers in the Changing Historical Context
}

\section{Why States Change Their Foreign Policy Behavior on the Global Stage}

\author{
Timofei V. Bordachev
}

\begin{abstract}
The latest changes in the nature of relations between members of the Western international community send us back to one of the fundamental questions in international relations: Are states able to change the nature of their behavior on the international stage? European integration and the formation of the Euro-Atlantic security space in the second half of the 20th century for a long time provided arguments in support of the changeability of the basic patterns of states' behavior and possible formation of a better, more civilized international system. However, growing contradictions within the West and its current policy,
\end{abstract}

\footnotetext{
Timofei Bordachev is an Associate Professor at the Faculty of World Economy and International Affairs, National Research University-Higher School of Economics (HSE), Director of the Centre for Comprehensive European and International Studies (CCEIS).

SPIN RSCI: 6872-5326

ORCID: 0000-0003-3267-0335

ResearcherID: E-9365-2014

Scopus AuthorlD: 56322540000

tel: $+7(495) 772-9590 * 22186$

e-mail: tbordachev@hse.ru

Office 427, Bldg.1, Malaya Ordynka Str. 17, Moscow, Russia

This article is greatly expanded and revised version of the paper written for the Valdai International Discussion Club. The original copy is available at: http://ru.valdaiclub.com/a/highlights/ dve-voyny-zapada/
} 
more forceful than that of non-Western great powers (Russia and China), call this assumption into question.

The article offers a historical analysis of two basic paradigms existing in the modern West: relations within it and confrontation with the outside world. The broad historical perspective makes it possible to view the existence of the fairly stable Western community over the past sixty to seventy years as a relatively short and specific period in the political history of the West, underlain not by the evolution of states' inner nature but by the external context. Changes in this context warrant a return to the traditional paradigm of behavior, which creates a paradox: Western great and major powers, primarily the United States, lead the way in revising the fundamental principles of the world order, while nonWestern great powers turn into its involuntary advocates.

Keywords: history of international relations, world order, Russia's foreign policy, great powers, revisionism.

\section{INTRODUCTION}

Abrupt changes in the U.S. foreign policy since 2017 have become a challenge not only to politicians but in equal measure to scholars as well. The Trump administration has been consistently questioning the validity of the key principles underpinning the liberal world order: the UN, the WTO, NATO, and the system of special strategic and economic relations with Europe-essentially everything that has recently been commonly known as the Western community. Academic discussions have been revolving around common speculations about a decline of the liberal world order which emerged after the end of the Cold War in the late 1980s and early 1990s and which many academics at that time regarded as the most stable structure of international relations ever created (Fukuyama, 1989). But the triumphant end of the Cold War also bore out another theory suggesting that the international community could be organized in a completely new way as a system of interstate relations "within" the West which are more civilized than the traditional hierarchy that remained dominant throughout the previous millennia of human history (Bull, 1966). 


\section{Timofei V. Bordachev}

Today the international Western community and the order being built around it as a system of rules and norms guiding relations between the Western community and the rest of the world, which largely remains anarchic (Buzan, 2008), are in crisis. As Richard Haas has recently noted in his article, "the fading liberal world order is neither liberal nor worldwide nor orderly" (Haas, 2018). Many experts point out that both the liberal world order and the Western community are essentially gone (Mead, 2018; Haas, 2018) and reevaluate them critically (Alison, 2018). A slightly more positive view suggests that the Western community is experiencing temporary but presumably solvable difficulties (Colgan and Keohane, 2017; Ikenberry, 2014; Lissner and Rapp-Hooper, 2018), but its advocates, too, are observing alarming trends in the foreign policies of the United States and other Western countries.

This raises a much broader theoretical question about the changeability of states' foreign policy behavior and its ability to evolve. Are the basic patterns of great powers' foreign policy behavior subject to fundamental change? Or do they retain their archetypical features in any historical context, and the result of their combined activities-transformation of the international system-depend entirely on changes in this very context? Answers to these fundamental questions can make an important contribution to the discussion on the nature, origin and prospects of relations between great powers. Studies exploring the historical evolution of foreign policy behavior patterns are plentiful, and different authors offer different approaches and hypotheses.

The strongest arguments supporting the changeability of these patterns within certain communities of states were put forth by British scholars in the 1960s when they came up with the idea of organized anarchy and the development of the international community as a new form of organizing the international system, within which states' traditional behavioral patterns change fundamentally, thus allowing them to overcome international anarchy. Hedley Bull defined the international community as "... a group of states (or, more generally, a group of independent political communities) which not merely form a system, in the sense that the behavior of each is a necessary factor in the calculations of the others, but also have established by dialogue and consent 
common rules and institutions for the conduct of their relations, and recognize their common interest in maintaining these arrangements" (Bull and Watson, 1984: 1). This approach is based on the assumption that states are able to evolve through a more complex understanding of their own national interests and consequently through more complex organization of the international system. This concept led to the division of the international system into two parts: a relatively more "civilized" one within which there emerged the international community-basically the West, and the "international society" - the rest of the world where interstate relations remain unstable (Buzan, 2005).

This approach impacted recent historical concepts regarding the strategic and political West as a historical community which for centuries has been building relations with the outside world by subordinating the latter to its own interests and values. Some researchers note the depth of institutional and sociocultural ties within the Western community which formed long before not even the rise but the emergence of the ancient Greek civilization (Morris, 2011). This specific feature preordained the future of Christian Europe at first as a separate civilizational center and then as a liberal community (Zakharia, 2011), which largely correlates with the idea of the Western international community. However, these concepts, as a rule, fail, partially or completely, to take into account the West's heterogeneity, both in terms of culture and political organization, and long periods of fierce conflicts between Western powers, thus leaving room for skepticism about its historically predetermined unity.

Historical studies of foreign policies of non-Western powers, which in different periods have opposed the West or cooperated with it, such as Russia, Japan or China, provide no evidence of any fundamental difference between their behavioral imperatives and those of Western great powers. For all the specific features of these countries' strategic and political cultures, determined by the historically established concepts of the external world ("Moscow is the third Rome," China is the Middle Kingdom), these states eagerly borrowed Western strategic and military concepts (Johnson, 1995). In Russia, a country having the closest relations with the West, Westphalian principles became part 


\section{Timofei V. Bordachev}

of its foreign policy identity and determined its foreign policy for a long time (Tsygankov, 2011). So, the long absence of the Westphalian foreign policy culture in these states should rather be viewed as an external context (Kissinger, 2015) and primarily as a result of their geographic remoteness from other centers of power.

The realist school traditionally pays attention to structural changes in the international system, which over the last two decades many researchers have viewed as an insufficient explanation for describing peculiarities in the foreign policy behavior of states. This prompted changes in the realist intellectual tradition itself. Neoclassical realism, which thrived in the late 1990s and early 2000s, essentially introduced internal political and sociocultural factors as independent variables in the analysis of foreign policy behavior (Rose, 1999). However, some researchers purposefully refused to include internal factors in international analysis and regarded the structure of international relations as the only factor that determined the behavior of states (Mearsheimer, 2006).

This methodological focus on the external context is regaining its relevance again as a way of analyzing international relations, with its validity being borne out by current political events. A historical analysis of the West's political history and relations with non-Western great powers makes it possible to trace, albeit cursorily, the evolution of these relations as a reflection of dominant patterns in the Western strategic culture.

\section{EVOLUTION OF THE INTERNATIONAL COMMUNITY OF WESTERN COUNTRIES}

The West's political history covers two and a half millennia of permanent struggle with both external forces and "internal" ones, that is, between Western states themselves. The first significant battle in the "external" war was the Battle of Marathon in 490 BC, when Greek poleis repelled the Persian Empire's aggression (Donlan and Thompson, 1976). The subsequent Greek-Persian wars stopped only with Alexander the Great's eastward advances when he ruined the Achaemenid dynasty and led his troops in the Battle of Hydaspes, the first armed 
clash between the West and the Indian civilization. In the 11th-13th centuries, Europeans took up arms and headed to the Middle East in a desperate, but doomed, attempt to seize the Holy Land. The situation changed dramatically in the 15th-16th centuries when the West's military-technical superiority over the rest of the world became overwhelming. In the fall of 1502, Vasco da Gama's caravels laid waste to the port of Kozhikode. Trade between the East and the West had moved completely into the ocean controlled by Europeans, while Eurasia had turned into deep and backward periphery. Nineteenth century opium wars became a logical end of this process, turning China, which considered itself the center of the world, into dependent periphery for many decades ahead.

As a result of several centuries of struggle, Europe and eventually America five hundred years ago established their virtually undivided political and military dominance in global affairs. The Westphalian system as a universal procedure of international interaction (Kissinger, 2014) was not spread peacefully by admitting new nations and getting them to adopt the common rules. It proceeded through the conquest by stronger and more successful nations of those countries which were not ready to defend their independence and exercise their sovereignty. Exceptions are few and unique-Russia and Japan, which eventually embarked on the path of expansionism themselves, with the latter surrendering part of its sovereignty in the 20th century. Europe lost its global significance as a result of two catastrophes in the last century-World Wars One and Two-but America is still fighting.

It is not possible to determine the date of the first battle in the West's internal war. One can only speak about major structural conflicts such as the Peloponnesian War or the Wars of the Diadochi, but long before them "internal" wars had become an important part of the West's political and cultural life, as borne out by Homer's Odyssey and especially the Iliad. However, it is known for certain when the last "internal" battle took place. It was the allies' Central European operation on March 22-April 11, 1945, when U.S., British, and French troops occupied the western part of Germany and part of Austria (Hart, 2015). The most important episode from the political and institutional point 


\section{Timofei V. Bordachev}

of view was the Thirty Years' War of 1618-1648, the 400th anniversary of the beginning of which is to be marked this year. That war, perhaps the most important one in history, led to the emergence of the world in which we live now. In other words, a purely internal episode in the West's history (neither China nor India were involved in the conflict, and Russia's indirect participation in that war was limited to the abortive siege of Smolensk in 1532 and went unnoticed in Europe) became an event of truly global significance. This probably explains the tradition to associate the West's achievements with the achievements of the whole mankind.

So, the hitherto permanent internal conflict ended in 1945, for the time being, at least. In the middle of last century, a unique community came into existence, where relations between its participants are based on principles other than those adopted in the international system. This community of values and interests is in fact the physical essence of what is commonly referred to in journalism as the "West." From the intellectual point of view, it was conceptualized by the authors of the English school of international relations theory in the second half of the 20th century (Buzan, 2014; Bull, 1966). Its representatives such as Hedley Bull and Barry Posen coined and introduced the terms 'international community' and 'international society.' Relations between states within the community are based on the fear of unfettered violence and are more perfect than outside it (Bull, 1966). Meanwhile, the "international society," that is, the rest of the world outside the West, continued to live by its traditional anarchic and egoistic rules (Buzan, 2008).

It is noteworthy that after the end of the first Cold War in 1991, a political and intellectual attempt was made to spread the notion of the "international community" to all the states (Nye, 1992). The socalled liberal world order established at that time relied politically on the theory of cohesive international community, whose interests and values were expressed and espoused by a group of Western countries led by the United States. This matched the situation created by the disintegration of the Soviet Union and was even fair in some ways. With Russia balancing on the verge of collapse and China "keeping a low 
profile" as bequeathed by Deng Xiaoping (Xiaoping, 1993), this group of states was expected to assume responsibility. Moreover, by acting on behalf of the whole mankind rather than its own, the West thought it was acting nobly. First of all, it rejected the centuries-old tradition of reveling in its victory. Secondly, it kindly invited the others to join in, naturally on the terms the winners were prepared to offer to ensure the priority of their own interests. Russia's refusal, albeit prompted by objective reasons, was taken with deep disappointment, which still lies at the heart of the attitude towards Moscow assumed by the overwhelming majority in the American establishment.

The question of how the country could become a member of this "international community" was and remains one of the most debatable points in the international and Russian political discourse. Many articles, reports and books addressed this issue until the end of the 2000s. Recipes varied from simple incorporation into the West as a junior partner (which would have taken Russian interests into account to a certain extent) and acceptance of Western values (Brzezinski, 1994) to more extravagant concepts of equal partnership and its institutionalization, among other things, as a union of Russia and Europe (Malcolm, 1994). However, the West is not only a community based on values and interests but also a regime, the existence of which is guaranteed by the hegemon. This role has always been played by the United States which has much more resources than the other participants. The exceptional ability of the Europeans to adapt to the twists and turns in the U.S. policy suggests that the objective reasons for such a state of affairs never change. Russia was prepared to accept the values and even share common interests with the West (Asmus, Kugler and Larrabee, 1993), but its participation in the regime was inherently impossible. So, Moscow botched several of the offered initiation ceremonies, including those in 1998-1999 after the events in Yugoslavia.

Even certain social models upholding values different from those espoused in Europe and its continuation in the New World were included, in full or in part, in the Western international community, for example, Japan, South Korea or Singapore (Medeiros, Crane, Heginbotham and Levin, 2008). And the reason why they are destined to 


\section{Timofei V. Bordachev}

remain among the U.S. allies is not the unique nature of relations between them, but local military-strategic considerations; in other words, it is their total dependence on Washington as their protector and hegemon. Whether these countries will be able to remain part of the West in case of their military-strategic emancipation (which is not anywhere in sight at the moment) is an open question.

\section{UNAVOIDABLE REVISIONISM IN THE HISTORICAL CONTEXT}

These two wars-internal and external-determined the West's behavior and strategic culture just as much as the Steppe molded Russia's strategic culture during the early Muscovite period, and remoteness from other centers of power shaped China's and India's customs. The closeness of the Steppe left Russia no choice but to continue permanent expansion and gather the lands (Lieven, 1995). Geographic remoteness prevented the Chinese and Indian civilizations from developing an ability to form alliances as a partner located so far away simply could not physically come to the other one's rescue. Currently, all the three major strategic non-Western cultures are in a situation where they have to adapt to the closest interaction, that is, to the environment which four hundred years ago gave birth to the Westphalian system as we know it.

Russia's territorial expansion is limited by demographic factors and international policy in Eurasia. After Russia's historical defeat in the Cold War and a dramatic decline in its possibilities, a bunch of independent states emerged on its borders, along with various interests developed by major external players. As a result, Russia no longer relies on force but builds international institutions and puts forth multilateral initiatives, such as Greater Eurasia-a strategic plan to create an international community in Eurasia, more cohesive and with closer relations between its participants than with third parties (Gleason, 2010; Emerson, 2014).

India and China are gradually becoming, and have largely already become, not an object of policy for other countries-Russia and the West-but a source of regional and global expansion in its own right (Wang, 2011). Their expansion should assume modern forms of 
multilateral cooperation; otherwise it will inevitably face strong opposition from their small, medium and even large neighbors. There have been attempts to counterbalance China through U.S.-led concepts welcomed by India and Japan (Wilson, 2018). It is a truism that overcrowded Europe, from Greek poleis to sovereign monarchies in the 17th century, has always been an ideal place for conflict (Bhattacharyya, 2011). This explains the "pertness" of European peoples but at the same time their incredible mobility and flexibility in creating more or less stable coalitions. In a historical perspective, vast expanses of the "external environment" looked like a space for expansion and colonization. There have been only two massive invasions of Europe in its entire history. In 711-732 Arabs from the Umayyad Caliphate seized almost the whole Iberian Peninsula and went all the way up to Loire until they were stopped and fought back by the Franks in the Battle of Poitiers (Deanesly, 1956). In the 16-17th centuries, Europe was attacked by Ottoman Turks. The Great Turkish War of 1683-1699 became the culminating point, after which Europe faced no threat of invasion ever again (Ágoston, 1999). Be it internal struggle or external expansion, but it took all of Europe's strength and resources. In the early 18th century, the possibility of such an expansion in the east was securely blocked by Russia. The Tsardom of Moscovy, the Russian Empire, and the Soviet Union moved westward themselves and succeeded in incorporating parts of Europe. In other directions the West encountered practically no restrictions and remained a source of continuous expansion. For two "long centuries"-the 18th (1648-1789) and the 19th (1789-1914) — the West's power spread around the world. By the time the European dominance began to decline, Western colonial powers controlled virtually all inhabitable lands but Russia and Japan.

The permanent internal conflict remained a norm as long as there was enough strength and there was no existential external threat. The West's cradle, Europe, was growing weaker and halted the internal struggle due to the devastating effects of the first half of the 20th century. With the U.S. support, there emerged the phenomenon of European integration - the most civilized form of interstate relations in history. This project became a panacea for European elites and the 


\section{Timofei V. Bordachev}

needed "reset" for the entire political system dating back to 1648. But for Europe the results of "the second thirty years" war" proved to be completely different from those of the first one in the 17th century. While four hundred years ago the internal conflict allowed Europeans to create rules, which they then spread to the rest of the world, events of 1914-1945, on the contrary, caused European states to lose their global significance. Since then Europe had to place many bets at the same time, as Raymond Aron put it (Aron, 1966). As a result, the North Atlantic Treaty Organization (NATO), the most stable military bloc in history, was created.

In both cases, in the first and the second Thirty Years' Wars, the conflict was started by forces that had been left out of the established system of rights and privileges. In the 17th century, it was initiated by the "rising powers" of that time-North European countries and France displeased with the dominant position of the Habsburgs in Central Europe. In the 20th century, this was done by other "rising powers"-Germany, Italy, and Japan-displeased with the gap between their increased possibilities and the lack of influence and prestige. It is not accidental that outstanding historian and political philosopher Edward Carr stated in 1939 that "what was commonly called the 'return to power politics' in 1931 was, in fact, the termination of the monopoly of power enjoyed by the status quo Powers" (Carr, 2001).

In the first quarter of the 21st century, the monopoly of power has been disrupted not only in the traditional, military, dimension. For the first time since 1991, Russia's operation in Syria has limited the United States' right to use the regime-change technique arbitrarily as the simplest way to solve foreign policy problems outside the "international community" of the West. China's Belt and Road strategy can put an end to the West's monopoly of economic and soft power. In recent years China's economic power and readiness to redistribute it have created a situation where small and medium countries outside of the Chinese periphery have been offered an alternative to international economic institutions controlled by the U.S. and its allies (Lomanov, 2017).

However, paradoxically, those who would seem to be interested in holding on to the existing order of things are actually pushing for con- 
frontation. Randall Schweller pointed to this paradox in his article in 2015: “...it is hegemons-both newly crowned and rising hegemons (a type of state that, to my knowledge, has not been discussed at all in the literature) - that are best positioned and most motivated to be revisionist powers" (Schweller, 2015). This is apparently the reason why power politics has been claimed so often now and ever since the end of the first Cold War by the states that won it, the United States and its European allies in the first place. The number of armed interventions they have undertaken over the past twenty-seven years is incomparable with similar endeavors by Russia, China, which has not fought with anyone at all, or all the other countries in the world. This leads one to agree with Schweller that it is Western powers that are the real revisionists seeking to revise international orders to make them more comfortable for themselves.

From the very start their revisionist drive targeted the fundamental principles of the world order as, having gained the upper hand in the first Cold War, they thought they had every right to change the world in accordance with their own views, interests, and values. No wonder there was so much talk in the 1990s and the early 2000s about the "end of the Westphalian system" and an emergence of a new system of coordinates, including the withering away of classical sovereignty (Engle, 2004). As Carr pointed out, it is those who can defend their sovereignty that talk about its dwindling importance most of all (Carr, 2001). The situation is getting even more interesting now. The main revisionist in human history, the United States, is once again leading the way by having its eccentric President Trump announce a strategy of unilateral benefits. This marks the final return to the struggle not for values but for resources and dominance, which is a classic and rather common occurrence in world history.

For its part, Russia has never called for revising the formal aspects of the world order. On the contrary, until 2014 it repeatedly stressed, at the official and expert levels, that international law must be respected and that the UN Security Council was the only legitimate body of the international community. China acted similarly. Although it was creating international financial institutions parallel to those controlled by 


\section{Timofei V. Bordachev}

the United States, it never questioned political institutions. The liberal world order that existed until recently satisfied China completely as it allowed it to save its strength and slowly position itself as a source of development resources, alternative to the West, for medium and small states, while making the most of globalization and taking resources and jobs away from its center and master-the United States. But the blessed dominance of global free trade is over for China.

Another paradox is that Russia's struggle with the West stems from the assumption that it is necessary to establish certain rules of the game, formally new, but essentially boiling down to the need for the West to comply with the requirements effective since the Peace of Westphalia of 1648: not to interfere in internal affairs, respect sovereign equality, and refrain from forcing domination upon others (Osiander, 2001). As a matter of fact, this clearly puts Moscow in a more vulnerable position amid the unfolding second Cold War, because in the traditional approach towards goal-setting in foreign policy, the purpose of the struggle is to maximize the gains, that is, the victory, rather than making an agreement or a deal. Agreements formalize the outcome of confrontation but do not determine its tasks and objectives. Russia, which is suspected of revisionism, is, in essence, seeking an agreement. Speaking in terms of classical international relations theory, its approach can be viewed as a position of relative weakness-while appealing to the minds and even the hearts of its partners in the U.S. and Europe amid an ongoing conflict, it may simply not be heard there.

It should be said that an agreement can be the purpose of the struggle only when the opponents recognize each other's legitimacy without any reservation (Kissinger, 2015), as they did during the Crimean War of 1853-1856, the most dramatic "diplomatic war" in the past four hundred years. Its main player, Emperor Napoleon III, sought not to carry out Palmerston's extravagant plans to seize Poland, the Baltic regions, the Crimea, and the Caucasus away from Russia, but to restore the balance of power in Europe (Croce, 1953), which he successfully did after taking Sevastopol. In the middle of the 19th century, just like now, Russia's opponents acted in a coalition. But back then, their relations were based on monarchic legitimacy, which at that time per- 
formed the same function the UN Charter performs today-to limit the arbitrary actions of stronger states. Russia and China are urging a return to such mutual legitimacy (Lukin, 2018).

However, the United States and its allies are a different story. After 1991 they have systemically and consistently been breaching the basic principles of international dialogue and international law. They had their own reason, rooted in the arguments used by Athenian envoys in Thucydides' "History of the Peloponnesian War:" "The strong do what they can and the weak suffer what they must," and those who are weaker should "submit before suffering the worst" (Thucydides, 2009). This did not work with small and hell-raising North Korea, but it did with formally weightier Iraq. Yugoslavia, a rather large European state, was demonstratively dismantled with the active assistance of EU countries which recognized its breakaway republics without the slightest hesitation. Europe's major powers consciously destroyed a sovereign state.

In 2003-2011, Western countries carried out direct armed interventions in Afghanistan, Iraq, and Libya. In the latter two cases, the West's actions resulted in the physical elimination of their leaders. A similar scenario was in the works for Syria, too, but suddenly ran into an obstacle - the Assad regime was supported by Iran and, which became crucial, Russia. Finally, after several years of constantly deteriorating relations, Russia was drawn into confrontation. The West's support for the coup in February 2014 in a country that was critically important for Russia left Moscow no choice. In late 2017, the U.S. officially pinned the label of opponent on China, which had been rather quiet compared to combative Russia. In response to the firm position on Ukraine, Russia came under economic pressure and faced regular attempts to isolate it. Meanwhile, a trade war is slowly but steadily unfolding against China.

In each of the examples above the West was proactive, with the U.S. and its allies leading the way, which was their policy pattern in the early period of the previous Cold War too (Davis, 1965). What we are seeing now is not the West's counterattack per se. A counterattack usually follows an attack, but no one has attacked the West. The "ris- 


\section{Timofei V. Bordachev}

ing powers"-China and Russia-have questioned the right of the U.S. and its allies to usurp decisions on international security issues and responded quite modestly where aggressiveness had gone beyond all reasonable limits. But no one started or even intended to start a systemic fight. Western powers initiated it themselves after the disappearance of the only deterrence - the powerful Soviet Union-in 1991. The West's distinctive feature is its immanent revisionism and, according to Schweller, its inherent "risk propensity and resolve to make changes to the existing order," and the fact that it never stops fighting and never becomes self-complacent (Schweller, 2015). This fighting is a natural state and has no alternative. It stops only when the opponent disappears from the map as an autonomous entity, usually by being incorporated into the West. The most vivid example was Japan after its defeat in World War II and the American occupation that followed it.

\section{NOT JUST A COLD WAR}

The new "world" war is marked by its major participants' reluctance to slide into a full-scale conflict (where all will die) and create numerous risky situations that may lead to such a conflict. In this respect it is similar to the last decades of the first Cold War in the second half of the $20^{\text {th }}$ century. This is the main reason why many are tempted to make the connection between the two. But such a connection would most likely become a fatal analytical simplification in terms of both systemic signs of a new global conflict and possible strategic decisions to be made by the participants involved.

The current situation cannot be viewed as a plain continuation of the previous Cold War. For example, the Second World War became a continuation of World War I due to the need to correct systemic imbalances that emerged after it, namely, Germany which was not defeated completely, and Japan which was unfairly left without its trophies. If Russia suffers a strategic defeat one more time, it will most likely not be allowed to rise again. If it comes to that, its partitioning could be the most radical scenario. But the context both inside and outside the country has changed dramatically. This was not the case during the inter-war period in 1919-1939 when all key international 
players remained the same, with Russia having only changed its imperial suit for the Bolshevik jacket.

Tactically and stylistically, current events in relations between Russia and the West are more similar to relations between the West and Soviet Russia in the 1920s-1930s. But everything has changed strategically since the end of the Cold War. First of all, the new round of the West's "external war" lacks a clearly articulated ideological component. The opponent advocates a radical ideology which rejects the fundamental principles of European values. Moreover, value pluralism is on the rise around the world. Secondly, all contexts have changed. What makes the current situation quite unique, as many have repeatedly observed, is that the policy pursued by the United States and its allies in the West's international community targets not some third-rate local dictatorship, but one of the nuclear super powers-developed and industrialized Russia, with China standing right behind it.

The internal conflict, within which confrontation was unfolding in the second half of the 20th century, was completely different. Against the background of total poverty in the majority of Asian and other countries, only the West could offer an attractive model of economic development. There is no doubt that the Soviet Union provided considerable assistance to its satellites and facilitated industrialization in some of them. But the economic model advanced by Moscow could not ensure sustainable development. China used this situation to its own advantage, while securing itself against a threat from the North at the same time. After decades of hardships-a war, the Cultural Revolution, and the Great Leap Forward-the Chinese authorities in the late 1970s opted for a policy of economic openness.

By now, the potential of economic "Westernization" of strategically important Asian states is largely, if not completely, exhausted. And although Russia experiences a critical lack of growth, it is no longer a poor country with a shortage of basic necessities, thanks to a market economy.

On the other hand, in the West itself the unique period of capitalism, when inevitable inequality in the distribution of income was offset by breathtaking economic growth rates in the 1940s-1970s, is over. 


\section{Timofei V. Bordachev}

With its reserves largely used up, the West is facing growing populism and uncertainty among people. Attempts to galvanize society through conflict, in this case with Russia, have not been sufficiently backed financially.

The external context has also undergone a dramatic transformation. The age of Europe ended in 1914, the age of America is coming to an end in front of our eyes, but the age of China will never come as all will try to contain it. So, the 21st century will be the age of Asia, with all systemic conflicts taking place in this most populated part of the world. The new global political geography has a completely different physical dimension-China and India have attained the status of world powers and have global ambitions.

More than a century and a half passed before China's admission into the Westphalian system triggered fundamental changes in its principles and development. India was included in the Westphalian system after it became an independent nation in 1947. But only now has it become a factor that affects the situation and the balance of power in the world. China and India are key members of the Rimland, control over which, according to classical geopolitics, allows oceanic powers to contain continental Russia (Spykman, 1944). Now these two countries are no longer a playing field but a source of global and regional expansion. As Henry Kissinger has said, the rise of China and India is more important for world politics than even the disintegration of the Soviet Union was (Kissinger, 2015). Perhaps this is what made a simultaneous attack on Russia and China inevitable. China is being contained; Russia is being attacked in hope to defeat it and get it incorporated, in part or in full, in the "international community" regime.

The West, without a doubt, has the experience of successfully fighting two opponents at the same time (Nazi Germany and imperial Japan). But in the past it had Russia on its side, a country with tremendous natural, geographic and mobilization resources. The West is now trying to turn India into its ally. The outcome will depend on whether permanent allied relations fit into India's strategic culture, which is not so obvious at this point. The United States' reckless moves threatening India's military-technical cooperation with Russia have already riled 
New Delhi (Strokan', Dzhordzhevich and Tarasenko, 2018). Narendra Modi's nationalist-oriented government cannot allow even such powerful countries as the United States to dictate with whom it should do business and with whom it should not. The U.S. has much more options for putting pressure on Russia than on India, let alone China which is tightly bound with Washington economically, or Europeans who are completely dependent on their American allies. Trade turnover between India and the U.S. in 2017 was $\$ 76$ billion, almost onetenth of America's trade turnover with China (Office of the U.S. Trade Representative, 2018). But most importantly, India does not need America to ensure its national security, while Washington needs good relations with New Deli to play its anti-Chinese game.

External and internal conditions in which the current conflict is unfolding cannot predetermine it outcome in favor of either side. This is perhaps what fuels Russia's resolve, which angers the West so much. Unfortunately, it would be another truism that Russia's relations with the U.S. and its allies are unlikely to improve in the foreseeable future. But this solves the problem of uncertain intentions-the most important methodological question in the international relations theory since Thucydides. The current intentions of the American bloc (including Europe which constantly hesitates and tries to play different cards) with regard to Russia, China or Iran are absolutely clear, and this creates unprecedented certainty in world politics in general.

\section{References}

Ágoston, G., 1999. Ottoman warfare in Europe 1453-1826. London: Palgrave. Aron, R.,1966. Peace and war: a theory of international relations. London: Weidenfeld and Nicolson.

Asmus, R., Kugler, R. and Larrabee, F., 1993. Building a new NATO. Foreign Affairs, 72(4), pp. 28-40. doi:10.2307/20045713

Bhattacharyya, S., 2011. Growth miracles and growth debacles: exploring root causes. UK: Edward Elgar.

Brzezinski, Z., 1994. The premature partnership. Foreign Affairs, 73(2), pp. 67-82. doi:10.2307/20045920 


\section{Timofei V. Bordachev}

Bull, H., 1966. International theory: the case for a classical approach. World politics, 18(3), pp. 361-377.

Bull, H. and Watson, A., 1984. The expansion of international society.

Buzan, B., 2008. People, states and fear: an agenda for international security studies in the post-Cold War era. Ecpr Press.

Buzan, B., 2014. An introduction to the English school of international relations: the societal approach. John Wiley and Sons.

Carr, E., 2001. The twenty years' crisis, 1919-1939: an introduction to the study of international relations. NY: Perennial.

Croce, B., 1953. History of Europe in the nineteenth century. Allen and Unwin.

Davis, S., 1965. Patterns and problems in U.S. foreign policy. International Affairs (Royal Institute of International Affairs 1944-), 41(4), pp. 624-636. doi: $10.2307 / 2610716$

Deanesly, M., 1956. A history of early medieval Europe, 476 to 911, (Vol. 1). Taylor and Francis.

Donlan, W. and Thompson, J., 1976. The Charge at Marathon: Herodotus 6.112. The Classical Journal, 71(4), pp. 339-343. Available at: <http://www.jstor.org/ stable/3298497> [Accessed 25 August 2018].

Engle, E. A., 2004. The transformation of the international legal system: the post-Westphalian legal order. QLR.

Emerson, M., 2014. Toward a Greater Eurasia: who, what, why, and how? Global Journal of Emerging Market Economies, 6 (1), 37.

Fukuyama, F., 1989. The end of history?

Gleason, A., 2010. Eurasia: What is it? Is it? Journal of Eurasian Studies, 1(1), 26. Hart, B. L., 2015. A history of the Second World War. Pan Macmillan.

Johnson, I., 1995. Thinking about strategic culture. International Security, Vol. 19, No. 4.

Kissinger, H., 2015. World order. NY: Penguin Books.

Lieven, D., 1995. The Russian Empire and the Soviet Union as imperial polities. Journal of Contemporary History, 30(4), pp. 607-636. Available at: <https:// www.jstor.org/stable/261085> [Accessed 28 August 2018].

Lukin, A., 2018. China and Russia. The new rapprochement. Moscow: Polity Press.

Malcolm, N., 1994. Russia and Europe: an end to confrontation? Pinter Pub Ltd. Mearsheimer, John, 2006. The tragedy of great power politics. 
Medeiros, E. S., Crane, K., Heginbotham, E. and Levin, N. D., 2008. Pacific currents: the responses of U.S. allies and security partners in East Asia to China's rise (Vol. 736). Rand Corporation.

Morris, A., 2011. Why the West rules - for now: The patterns of history, and what they reveal about the future.

Nye, J. S., 1992. What new world order? Foreign Affairs, 71(2), pp. 83-96.

Osiander, A., 2001. Sovereignty, international relations, and the Westphalian myth. International organization, 55(2), pp. 251-287.

Schweller, R. L., 2015. Rising powers and revisionism in emerging international orders. Russia in Global Affairs, 7.

Spykman, N. J. and Nicholl, H. R., 1944. Geography of the peace. UK: Gazelle Book Services Ltd.

Thucydides, B., 2009. The history of the Peloponnesian War. (Annotated).

Tsygankov, A., 2013. Russia's foreign policy: change and continuity in national dentity.

U.S.-India Bilateral Trade and Investment, 2018. Office of the United States Trade Representative.

Xiaoping, D., 1993. Selected works of Deng Xiaoping. Beijing: Publishing House of the People.

Wang, V. W. C., 2011. "Chindia" or rivalry? Rising China, rising India, and contending perspectives on India-China relations. Asian Perspective, 35(3), pp. 437-469.

Wilson, J. D., 2018. Rescaling to the Indo-Pacific: from economic to securitydriven regionalism in Asia. East Asia, 35(2), pp. 177-196.

Lomanov A., 2017. Strategiia kulturnogo vliianiia Kitaia v proekte "Odin poias, odin put'" [The strategy of China's cultural influence on "One Belt, One Road" project]. In: Kitai v mirovoi i regionalnoi politike. Istoria i sovremennost [China in world and regional politics. History and modern times]. 22 (22), pp. 52-63. doi: 10.24411/9785-0324-2017-00004

Strokan' S., Dzhordzhevich A. and Tarasenko P., 2018. "Dva plus dva" umnozhaiut na nol' ["Two plus two" multiplied by zero]. Available at: <https:// www.kommersant.ru/doc/3662603> [Accessed 29 August 2018].

Zakharia, F., 1997. Rise of liberal democracy. Foreign Affairs, 76(6). 